\title{
Opioid Activity of Nitrous Oxide and Ketamine
}

\author{
Mark A Gillman* \\ Emeritus CEO South African Brain Research Instituted, South Africa \\ *Corresponding Author: Mark A Gillman, Emeritus CEO South African Brain Research Instituted, South Africa.
}

Received: August 30, 2019; Published: September 13, 2019

DOI: 10.31080/ASDS.2019.03.0642

I read the excellent recent paper by Eslaamisaad and Topic [1] with interest. Nonetheless, some of their statements need modification. For instance, they state "Recent studies have suggested that both $\mathrm{N}$ - methyl - D - aspartate (NMDA) and Gamma - aminobutyric acid type A (GABA - A) receptors are affected by nitrous oxide" and later in the paper "Ketamine generates its effects through an antagonistic action on NMDA receptors...." Unfortunately, there is no mention of the opioid system in the actions of either nitrous oxide or ketamine.

There is good and abundant evidence clearly showing that the endogenous opioid substances and receptors are involved in the actions of both nitrous oxide $\left(\mathrm{N}_{2} \mathrm{O}\right)$ and ketamine.

First, let us look at the evidence for endogenous opioid participation in the actions of nitrous oxide $\left(\mathrm{N}_{2} \mathrm{O}\right)$. Readers will note that these studies have been conducted in both animals and man, conclusively showing that $\mathrm{N}_{2} \mathrm{O}$ has opioid properties $[2,3]$. Some of these publications indirectly implicate the endogenous opioid system in the actions of $\mathrm{N}_{2} \mathrm{O}$ [4-11]. There are also radio - receptor binding studies that indicate that $\mathrm{N}_{2} \mathrm{O}$ acts directly on opioid receptors, in animals [12,13] and man [14]. It is also of interest that $\mathrm{N}_{2} \mathrm{O}$, and not nitric oxide (NO), was the first gas to have been showed to have a role in neurotransmission $[15,16]$. It is also clear from some these studies that $\mathrm{N}_{2} \mathrm{O}$ is a partial opioid agonist $[2,3]$.

Second there is also good evidence, that ketamine interacts with endogenous opioid system [8,17-20]. Although more research needs to be done to establish whether it does so by binding directly to opioid receptors (like $\mathrm{N}_{2} \mathrm{O}$ ) or merely by provoking the release of endogenous opioids.
Of course, they are quite correct in averring that $\mathrm{N}_{2} \mathrm{O}$ interacts with other receptor systems apart from the opioid system [1].

These authors [1] also mention that "The dose of nitrous oxide is $50 \%$ combined with $50 \%$ oxygen in the mixture". There are good reasons to take issue with the routine use of a 50:50\% mixture of nitrous oxide and oxygen. Rather the required concentration of $\mathrm{N}_{2} \mathrm{O}$ should be titrated to the individual requirements of each patient, by employing the gentler dental titration technique, to avoid unnecessary side effects. The side effects associated with a fixed $50 \%$ mixture of $\mathrm{N}_{2} \mathrm{O}$ and oxygen include, nausea, vomiting, pre - anaesthetic excitation or even actual anaesthesia [20-22].

I think it is important to bring this information to the attention of your readers.

\section{Funding sources}

Nil.

\section{Conflict of Interest}

I have been researching and publishing on the psychotropic properties of nitrous oxide for over 40 years. Since 2003, I have been a medical adviser to Sedatek, a South African company that supplies equipment for administering low concentrations of nitrous oxide in South Africa, predominantly among dentists. I own no shares in the company.

\section{Bibliography}

1. Eslaamisaad S and Tophci S. "Sedation in Pediatric dentistry". Acta Scientific Dental Sciences 3 (2019): 40-46.

2. Gillman MA. "Analgesic [sub anaesthetic] nitrous oxide interacts with the endogenous opioid system: A review of the evidence". Life Sciences 39.14 (1986): 1209-1221. 
3. Gillman MA. "Analgesic nitrous oxide should join the opioid family after almost two centuries". South African Journal of Science 89 (1993): 25-27.

4. Berkowitz BA., et al. "Nitrous oxide analgesia: resemblance to opiate action”. Science 194.4268 (1976): 967-968.

5. Finck AD., et al. "Nitrous oxide selectively releases met5-enkephalin and met5-enkephalin-arg6-phe7 into canine third ventricular cerebrospinal fluid". Anesthesia and Analgesia 80.4 (1995): 664-670.

6. Quock RM., et al. "Dose-dependent antagonism and potentiation of nitrous oxide antinociception by naloxone in mice". Journal of Pharmacology and Experimental Therapeutics 267.1 (1993): 117-122.

7. Hara S., et al. "Effect of opioid peptide antiserum on nitrous oxide antinociception in rats". Pharmacology Biochemistry and Behaviour 48.3 (1994) 8: 699-702.

8. Finck AD., et al. "Irreversible opioid receptor blockade decreases the analgesic effects of ketamine and nitrous oxide in mice". Anesthesiology 69 (1988): A604.

9. Finck AD., et al. "Nitrous oxide selectively releases met5-enkephalin and met5-enkephalin-arg6-phe7 into canine third ventricular cerebrospinal fluid". Anesthesia and Analgesia 80.4 (1995): 664-670.

10. Gillman MA., et al. "Paradoxical effect of naloxone on nitrous oxide analgesia in man". European Journal of Pharmacology 61.2 (1980): 175-177.

11. Gillman MA and Lichtigfeld FJ. "A comparison of the effects of morphine sulphate and nitrous oxide on chronic pain states in man". Journal of Neurological Sciences 49.1 (1981): 41-45.

12. Daras C., et al. "3[H]-Naloxone displacement: evidence for nitrous oxide as an opioid agonist". European Journal of Pharmacology 89.1-2 (1983): 177-178.

13. Ori C., et al. "Effects of nitrous oxide and halothane on mu and kappa opioid receptors in guinea- pig brain". Anesthesiology 70.3 (1989): 541-544.

14. Van Heerden BB., et al. "The effect of nitrous oxide on the endogenous opiate system". Journal of Nuclear Medicine 33 (1992): 883-884.

15. Gillman MA. "Nitrous oxide, Nitric oxide and neurotransmission". British Medical Journal 305 (1992):1368.
16. Gillman MA and Lichtigfeld FJ. "NO comments". Nature 367 (1994): 28.

17. Hirota K1., et al. "Stereoselective interaction of ketamine with recombinant $\mathrm{mu}$, kappa, and delta opioid receptors expressed in Chinese hamster ovary cells". Anesthesiology 90.1 (1999):174-182.

18. Sarton E1., et al. "The involvement of the mu-opioid receptor in ketamine-induced respiratory depression and antinociception". Anesthesia and Analgesia 93.6 (2001): 1495-1500.

19. Finck AD and Ngai SH. "Opiate receptor mediation of ketamine analgesia”. Anesthesiology 56.4 (1982): 291-297.

20. Gillman MA. "Words of caution on using fixed $50 \%$ concentrations of nitrous oxide in psychiatry". Clinical Psychopharmacology 39.4 (2019): 421-422.

21. Malamad SF. "Sedation: A guide to patient management". 2nd Edition, St Louis: Mosby, (1989).

22. Smith RA and Beirne OR. "The use of nitrous oxide by dentists". In: Eger, E.I. 11 ed, Nitrous oxide/N2O., New York: Elsevier, (1985): 281-304.

\section{Volume 3 Issue 10 October 2019 (C) All rights are reserved Mark A Gillman.}

